\title{
Temporal Variation of Intertidal Seagrass in Southern China (2008-2014)
}

\author{
Guanglong Qiu ${ }^{1,2,3}$, Frederick T. Short ${ }^{4}$, Hangqing Fan ${ }^{2}$, and Guohua Liu ${ }^{1,3 *}$ \\ ${ }^{1}$ State Key Laboratory of Urban and Regional Ecology, Research Center for Eco-environmental Sciences, Chinese Academy of \\ Sciences, Beijing 100085, China \\ ${ }^{2}$ Guangxi Key Laboratory of Mangrove Conservation and Utilization, Guangxi Mangrove Research Center, Guangxi Academy of \\ Sciences, Beihai 536000, China \\ ${ }^{3}$ University of Chinese Academy of Sciences, Beijing 100049, China \\ ${ }^{4}$ Jackson Estuarine Laboratory, University of New Hampshire, Durham NH 03824, USA
}

Received 7 January 2017; Revised 14 March 2017; Accepted 22 March 2017

(C) KSO, KIOST and Springer 2017

\begin{abstract}
Understanding the temporal dynamics of seagrasses and the major influences on seagrass growth is critical for seagrass habitat conservation and administration. However, little work has been done regarding these issues in southern China. To examine inter-annual and seasonal variations of the intertidal Halophila ovalis community in southern China, we conducted quarterly sampling using the SeagrassNet methodology and assessed environmental conditions as well as direct anthropogenic impacts on the seagrass meadow from July 2008 to October 2014. Our study demonstrated strong inter-annual and seasonal dynamics of the intertidal seagrass meadow in the study area. Generally, the community performed best (highest seagrass cover, leaf area, shoot density, total biomass) in summer and worst in spring among the 4 seasons. The temporal variations in the seagrass community attributes (e.g. above-ground biomass) were significantly affected by precipitation, atmospheric visibility, and salinity, while leaf width was significantly negatively correlated with temperature, atmospheric visibility and salinity. Temperature was a major factor influencing the seagrass community (both macroalgae and seagrass), with temperature data showing an inverse relationship between seagrass and macroalgae. The aboveground: below-ground biomass ratio and leaf width of $H$. ovalis were the most sensitive plant parameters monitored when assessing environmental interactions. Human physical disturbances did not have a significant effect on seagrass dynamics in the study area. We concluded that long-term monitoring (like SeagrassNet) is valuable in understanding the relationship between environmental variables and seagrasses.
\end{abstract}

Keywords - SeagrassNet, Halophila ovalis, seasonality, seagrass monitoring, human disturbance, seagrass dynamics

\footnotetext{
*Corresponding author. E-mail: ghliu@rcees.ac.cn
}

\section{Introduction}

Seagrass communities have long been recognized to exhibit dynamics over various temporal scales (Duarte et al. 2006; Lin and Shao 1998; Robbins and Bell 2000). Globally, considerable effort has been made to investigate the temporal dynamics of seagrass communities and to explore their relationship with external environmental factors (Duarte et al. 2006; Erftemeijer and Herman 1994; Jankowska et al. 2014; Kim et al. 2014; Kuo and Lin 2010; Short et al. 2014). However, in China, previous seagrass research has focused on seagrass distribution and structure, while data on temporal dynamics are scarce (den Hartog and Yang 1990; Lin and Shao 1998; Zhang et al. 2015, 2016; Zheng et al. 2013; Zhou et al. 2015).

China's southern coasts (Hainan, Guangxi and Guangdong), rich in seagrass diversity ( 15 species), account for more than $80 \%$ of the country's total seagrass area (Zheng et al. 2013). One of the most predominant seagrass species in this region is Halophila ovalis (Zheng et al. 2013), which is also common throughout the Indo-Pacific (Nguyen et al. 2014). Little information exists on long-term ( $>5 \mathrm{yr}$ ) dynamics of $H$. ovalis in China; studies have focused mainly on community structure, eco-physiology, etc., or have been conducted over a relatively short period ( $<2$ yr) (Huong et al. 2003). Direct anthropogenic physical perturbations of seagrass (i.e., digging or raking commercial clams or Sipunculus worms) are a frequent disturbance in the South China Sea (UNEP 2008), but these effects have not been extensively studied. Worldwide, direct physical disturbance is a significant source of localized 
seagrass habitat destruction, with the potential for large-scale cumulative impacts (Fonseca et al. 1998), and may pose a severe threat to seagrass (Neckles et al. 2005) or may alter seagrass reproduction (Alexandre et al. 2005; Fonseca et al. 1998). In this study, we assess the inter-annual and seasonal dynamics of seagrass cover, biomass, shoot density, plant size, etc. over a 6-year period (July 2008 through October 2014), as well as the associated environmental parameters and human physical disturbances, at a subtropical intertidal $H$. ovalis meadow in Beibu Gulf, China. SeagrassNet is an expanding, worldwide ecological monitoring program that investigates and documents the status of seagrass resources and the threats to this important and diminishing marine ecosystem. The program started in 2001 in the Western Pacific and now includes 134 sites in 33 countries, employing a global monitoring protocol (www.seagrassnet.org; Short et al. 2006b). Using the SeagrassNet monitoring protocol, we examined the temporal dynamics of a subtropical intertidal $H$. ovalis community over various time scales to determine the primary forcings (environmental factors vs. man-made physical disturbances) controlling the temporal changes of this seagrass community in southern China.

\section{Materials and Methods}

\section{Study site}

The seagrass study site is located near the Zhuling Saltern (salt production field) in the Beibu Gulf of the South China Sea, $25 \mathrm{~km}$ from Beihai, Guangxi Province, China (Lat. $21^{\circ} 26.075^{\prime} \mathrm{N}$, Long. $109^{\circ} 16.889^{\prime} \mathrm{E}$ ) (Fig. 1). The seagrass meadow is at the shoreward edge of a vast intertidal sand flat that is divided into thousands of shellfish and worm aquaculture plots and is influenced by abundant rainfall in the wet season from the low latitude subtropical monsoon. The reservoir close to the meadow is one of the largest ponds for the storage of sea water at Zhuling Saltern (Fig. 1). Sea water flows into the site through a tidal gate in the concrete seawall that forms the reservoir for seawater storage at the Zhuling Saltern.

The intertidal seagrass bed, facing open coastal water, is dominated by $H$. ovalis, interspersed with small patches of

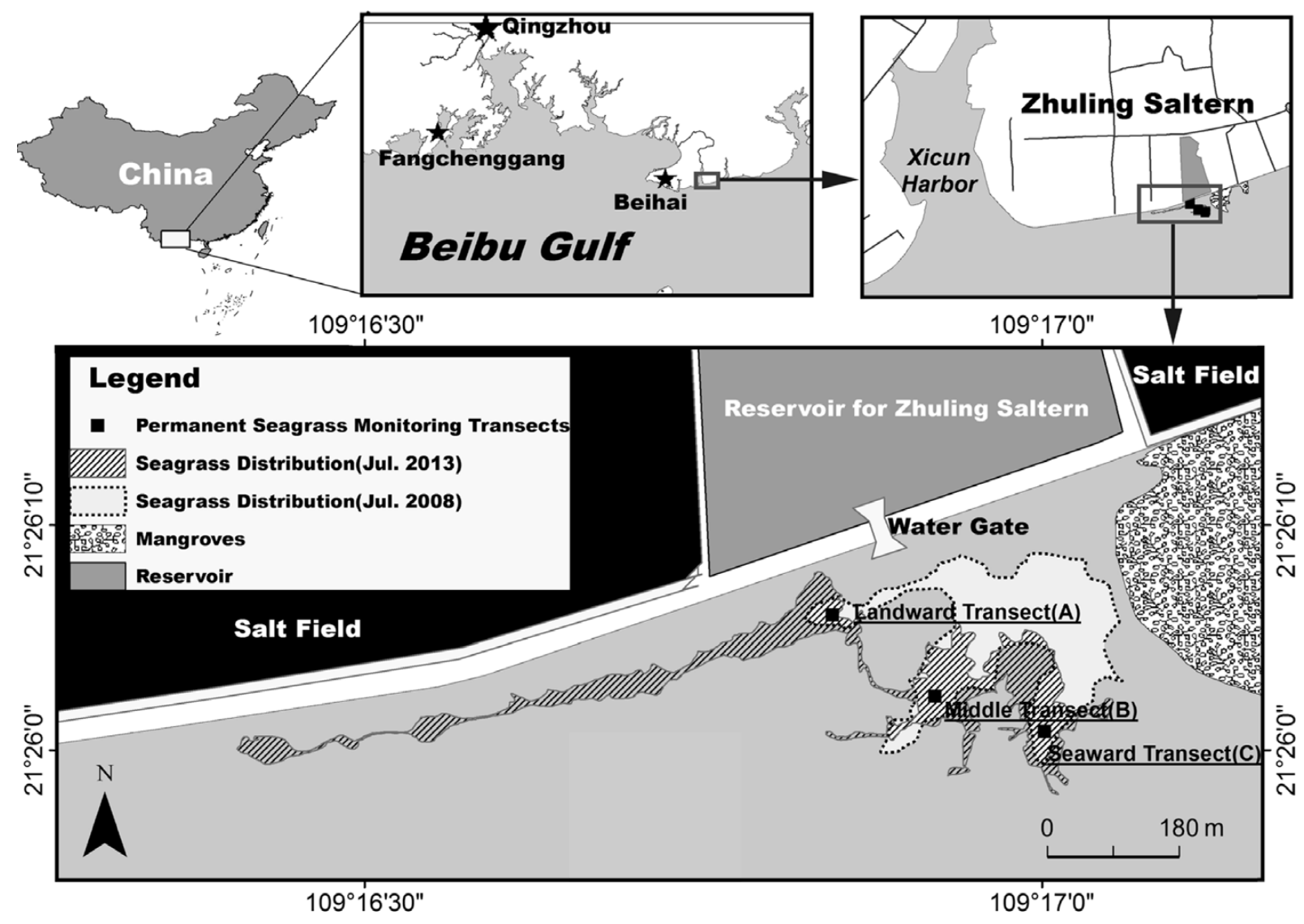

Fig. 1. Location of the study area, the $50 \mathrm{~m}$ SeagrassNet monitoring transects and seagrass and mangrove distribution 


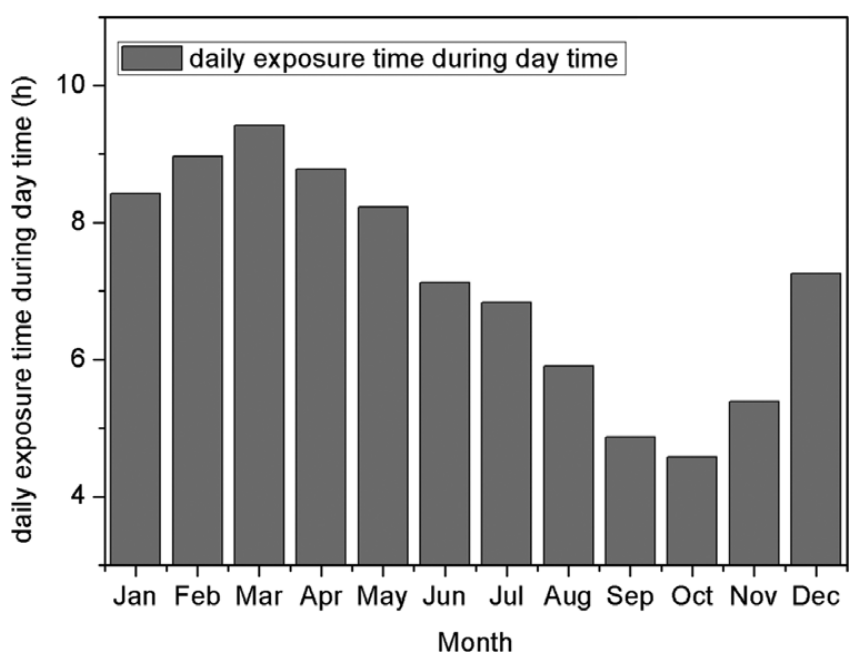

Fig. 2. Predicted daily exposure time during the day for each month in 2013

Zostera japonica and Halodule uninervis (accounting for $<2 \%$ of the total area). The seagrass bed receives no government protection and is freely accessed for commercial clam and worm digging (Zheng et al. 2013). The Guangxi Mangrove Research Center joined SeagrassNet in 2008 and set up a monitoring site at Zhuling. Since July 2008, regular quarterly monitoring has been carried out.

The tide in the study area is irregular and diurnal, with the extreme high water level during syzygy tide, the lowest water level during neap tide and a mean tidal level of 3.42, 2.15 and $0.36 \mathrm{~m}$, respectively (Xun et al. 2006). Based on the predicted tidal level data published by the State Ocean Administration (NMDIS 2012) and our observations of tidal height markers within the seagrass beds during ebb and flood tide, we calculated the daily mean exposure times during the day to range from 4.5-9.5 hours (Fig. 2).
Some of the physical and chemical parameters of sea water in the study area are presented as Table 1.

\section{Methodology \\ Field work and laboratory analysis}

On July 12, 2008, we began quarterly seagrass monitoring at the site using standard SeagrassNet methods (Short et al. 2006b; www.SeagrassNet.org). In brief, three permanent, parallel $50-\mathrm{m}$ transects were established, their midpoints located on a line perpendicular to the shore. These transects were located at the nearshore, mid-depth, and deep parts of the seagrass meadow. At each transect, twelve $50 \times 50-\mathrm{cm}$ fixed quadrats were randomly chosen, resulting in a total of 36 permanent random quadrats at the site. We then measured seagrass percent cover (PC) and macroalgae percent cover (MAPC), seawater salinity (SAL) and seagrass canopy height $(\mathrm{CH})$. Seagrass sample cores (diameter $=7 \mathrm{~cm}$ ) were collected to determine plant parameters. In the laboratory, we analyzed shoot density (SD), leaf width (LW), above-ground biomass (AGB), below-ground biomass (BGB), total biomass (TB), flower/fruit density (FD), and percent cover of epiphytes on seagrass leaves (EPPC) based on these core samples. We also counted the number of quadrats with seagrass present and calculated the percentage of total quadrats (PQS) with seagrass for each season.

We used a handheld GPS (Garmin etrex20) to map seagrass distribution in July 2008 and 2013. The GPS data were then imported to ArcGIS 10.0 (ESRI, USA) to create a distribution map of the seagrass meadow.

Starting in July 2009, leaf area index (LAI) was measured quarterly using a portable leaf area meter (ADC, U.K.) in the laboratory. All of the $H$. ovalis leaves harvested in each core sample were measured separately.

Table 1. Chemical parameters of seawater in the Zhuling seagrass bed, Beihai, Guangxi, China (Sampling date, Jan. 13, 2015) (SAQSIQ 2007)

\begin{tabular}{|c|c|c|c|c|c|c|c|c|c|}
\hline $\begin{array}{c}\text { Sampled } \\
\text { water type }\end{array}$ & Transect & $\begin{array}{c}\text { Inorganic } \\
\text { phosphorus }^{\mathrm{a}} \\
(\mu \mathrm{M})\end{array}$ & $\begin{array}{l}\text { Nitrite }^{b} \\
(\mu \mathrm{M})\end{array}$ & $\begin{array}{l}\text { Nitrate }^{\mathrm{c}} \\
(\mu \mathrm{M})\end{array}$ & $\underset{(\mu \mathrm{M})}{\text { Ammonia }^{\mathrm{d}}}$ & $\begin{array}{c}\text { Total } \\
\text { nitrogen }^{\mathrm{e}} \\
(\mu \mathrm{M})\end{array}$ & $\begin{array}{c}\text { Total } \\
\text { phosphorus }^{\mathrm{e}} \\
(\mu \mathrm{M})\end{array}$ & $\begin{array}{l}\text { Organic } \\
\text { carbon }^{\mathrm{f}} \\
(\mu \mathrm{M})\end{array}$ & $\begin{array}{c}\text { Chlorophyll } \mathrm{a}^{\mathrm{g}} \\
(\mu \mathrm{g} / \mathrm{L})\end{array}$ \\
\hline \multirow[t]{3}{*}{ Overlying water } & A & 0.178 & 0.300 & 2.600 & 2.809 & 24.263 & 1.130 & 226 & 1.14 \\
\hline & B & 0.356 & 0.150 & 0.596 & 3.064 & 33.107 & 1.079 & 197 & 2.19 \\
\hline & $\mathrm{C}$ & 0.267 & 0.321 & 0.922 & 4.843 & 24.036 & 1.233 & 169 & 2.94 \\
\hline \multirow[t]{3}{*}{ Pore water } & A & 6.763 & 0.364 & 0.879 & 0.005 & 303.855 & 8.321 & 836 & I \\
\hline & B & 0.667 & 0.236 & 1.007 & 5.297 & 47.392 & 1.490 & 210 & l \\
\hline & $\mathrm{C}$ & 2.002 & 0.321 & 0.176 & 2.814 & 88.435 & 4.007 & 271 & / \\
\hline
\end{tabular}

Analytical method: ${ }^{a}$ Phosphorus molybdenum blue spectrophotometric method; ${ }^{b}$ Naphthyl ethylenediamine method; ${ }^{\circ}$ Cadmium reduction column method;

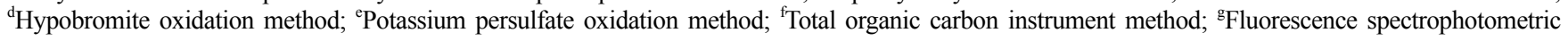
method 
To evaluate the degree of human-induced physical disturbance from invertebrate harvesting at the site, three $50 \mathrm{~m} \times 50 \mathrm{~m}$ plots were permanently marked. Each plot was formed by the SeagrassNet 50-m transect, extending seaward by $50 \mathrm{~m}$. The area that was dug or buried within each plot was assessed visually, and the percentage of the total area $(3 \times 50 \times 50=$ $7500 \mathrm{~m}^{2}$ ) was calculated.

An underwater fluorometer (DIVING-PAM, Heinz Walz $\mathrm{GmbH}$, Germany) was used to determine seagrass florescence as a measure of photosynthesis. The ratio of variable to maximum fluorescence $(F v: F m)$ provides information on the state of the PSII photochemical apparatus, often termed photosynthetic efficiency (Ralph et al. 1998). Measurements of $F v: F m$ were made using 14-18 dark-adapted leaves (4 6 leaves for each transect) (Ralph et al. 1998) in all seasons in 2013.

\section{Climate data}

We deployed 5 HOBO light and temperature sensors at stations $\mathrm{A}$ and $\mathrm{C}$ and on land during each season according to the SeagrassNet protocol. However, during the 6-year monitoring period, a total of 37 sensors were lost and very few data were obtained. Therefore, temperature and visibility (comparable to measures of available light) recorded at the Beihai meteorological station (the weather station is $\sim 23 \mathrm{~km}$ straight-line distance to the study site) supplemented the sensor data. The climate data (daily precipitation, temperature, min. temperature, max. temperature, atmospheric visibility, wind speed, max. wind speed) were downloaded from the Climate Center of Utah State University website (Climate. usurf.usu.edu, Beihai Meteorological Station (BMS)). Temperature, visibility, and wind speed data for each season were averaged based on values collected $7,15,30$, and 60 days before each monitoring effort. The total rainfall for each time period was used, while for maximum wind speed and maximum (and minimum) temperature, the highest (and lowest) values from each time period were used.

The BMS temperature data and the HOBO sensor-recorded temperature data from the study site were subjected to a Pearson correlation test, and a highly significant positive correlation was found between the two datasets $(r=0.989, p$ $<0.01, \mathrm{~N}=368$, daily average data from $2011 / 04 / 17$ to $2012 / 04 /$ 18 , method $=$ Pearson). Similarly, there was a strong linear correlation $(r=0.717, p<0.01)$ between the BMS visibility data and the HOBO light data.

\section{Statistical analysis}

All data are presented as the mean \pm S.E. Statistical analyses were performed using the SPSS package (20.0, SPSS Inc.). Seasonal variations of the reported variables were analyzed by one-way analysis of variance (ANOVA). When significant effects were detected by ANOVA, a posteriori comparisons were performed using the Games-Howell test. Data were tested for normality and homogeneity of variance to meet the assumptions of parametric statistical analysis. The relationships between environmental parameters (and man-made perturbation) and the attributes of the seagrass community were analyzed using the Pearson correlation test.

\section{Results}

\section{Abiotic factors}

\section{Climate variables}

The $\sim 6$ years of temporal variations of seven climate variables are presented in Fig. 3. Distinctive temporal fluctuations can be observed in monthly rainfall, wind speed, atmospheric visibility and temperature. The mean monthly rainfall was $188 \mathrm{~mm}$. The seasonal variation in rainfall was profound, with the maximum occurring during the rainy monsoon season of June-August, with very little rainfall during the winter season. Two very high precipitation events occurred, one in June 2008 (955 mm) and the other in August 2014 (1026 mm). No rainfall was observed in November 2010 or January 2014 (Fig. 3A).

The average wind speed during the study period was 9.3 knots (Fig. 3B). Most strong typhoons appeared between July and September. A super typhoon (Rammasun or Weimaxun, No. 1409), the strongest typhoon in four decades in Southern China, brought strong wind and rain to the study area, with a maximum wind speed of 78 knots on July 18, 2014. On Sep 16, 2014 , there was another typhoon, with a wind speed of 53 knots.

Average atmospheric visibility was $7.8 \mathrm{~km}$, with poor visibility from January to March each year and high visibility from June to September (Fig. 3C). The mean air temperature during the study period was $23.3^{\circ} \mathrm{C}$ (Fig. 3D). Generally, the lowest temperatures were recorded in January and February. On January 11 and 12, 2011, the lowest temperatures of the study period were observed, i.e., $3.4^{\circ} \mathrm{C}$ and $3.5^{\circ} \mathrm{C}$, respectively. In January 2011 , the average temperature was $9.6^{\circ} \mathrm{C}$. The highest temperature was usually observed from June to August. The highest temperature during the study period was $38.4^{\circ} \mathrm{C}$, recorded on July 28, 2008 (Fig. 3D). 
(A)

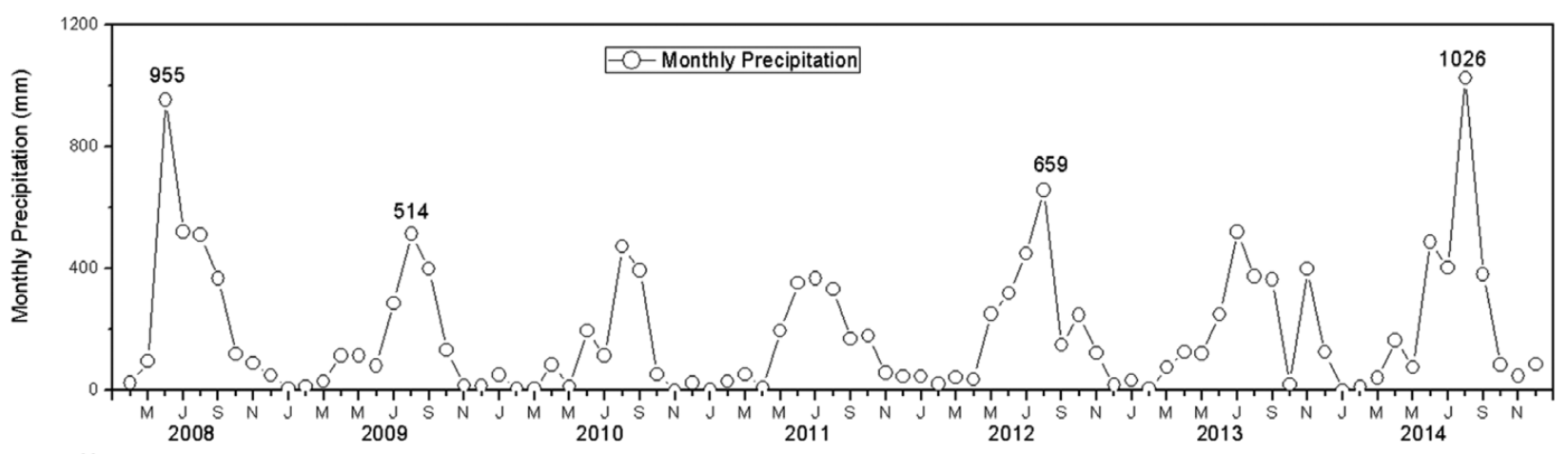

(B)

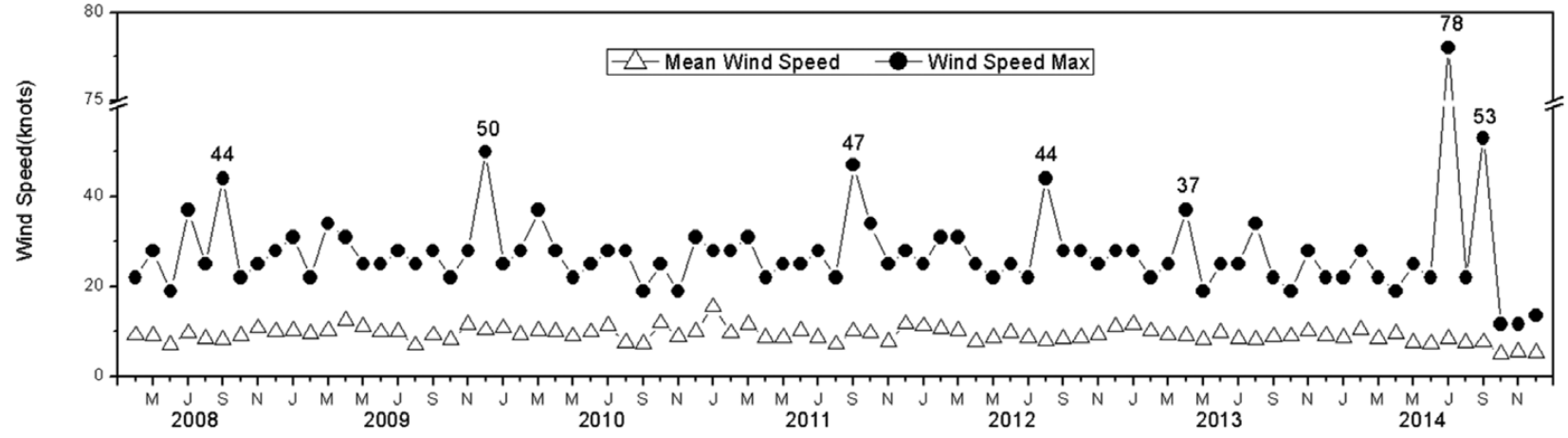

(C)

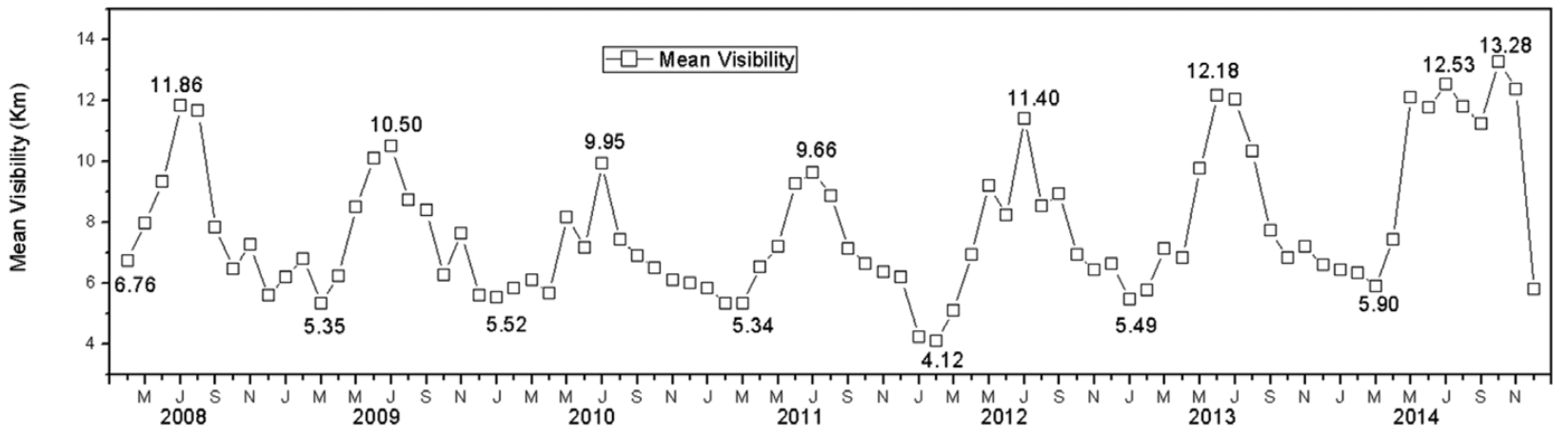

(D)

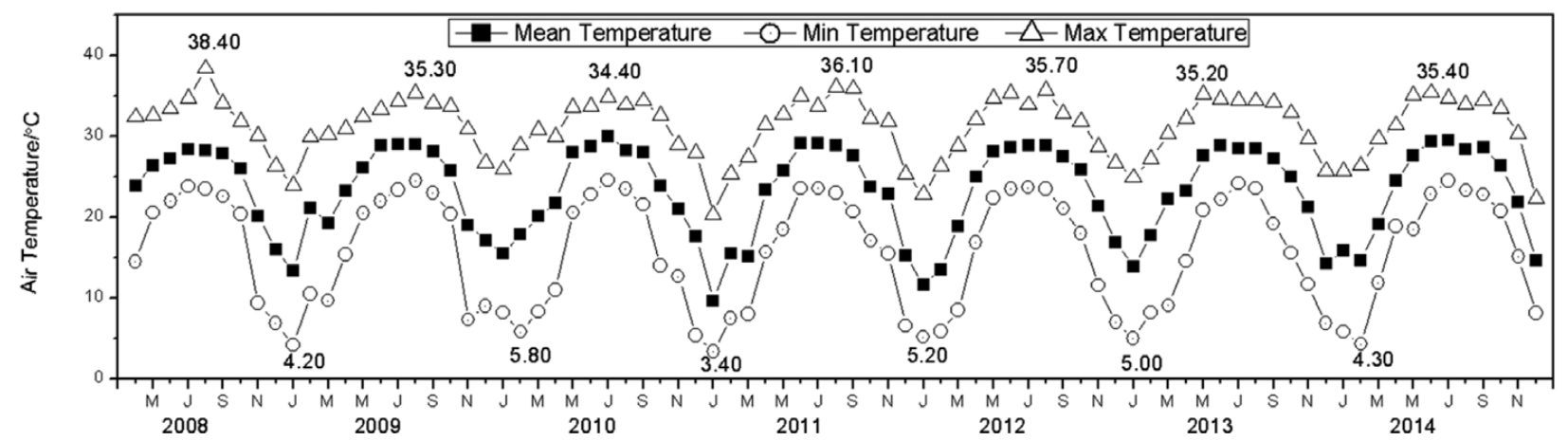

Fig. 3. Monthly climate data in the study area (Apr. 2008 Dec. 2014). A. precipitation sum of each month; B. mean and max wind speed; C. mean atmospheric visibility; D. mean, minimum and maximum air temperature (Climate.usurf. usu.edu)

\section{Seawater salinity}

The salinity of the sea water fluctuated, and a clear seasonal pattern was observed (Fig. 4). Winter had the highest salinity of $31.0 \pm 0.7 \mathrm{psu}$, which was higher than that recorded during spring, i.e., $30.1 \pm 1.9 \mathrm{psu}(\mathrm{p}>0.05)$, followed by autumn, with a salinity of $28.3 \pm 1.2 \mathrm{psu}$. The lowest salinity, $24.5 \pm$ $1.9 \mathrm{psu}$, was measured in summer; this value was significantly lower than that measured in winter $(\mathrm{p}<0.05)$ and spring $(\mathrm{p}<$ 0.05 ) but not autumn $(\mathrm{p}>0.05)$ (Fig. 5). An overall average salinity of 28.3 psu was calculated. The salinity in July 2008 


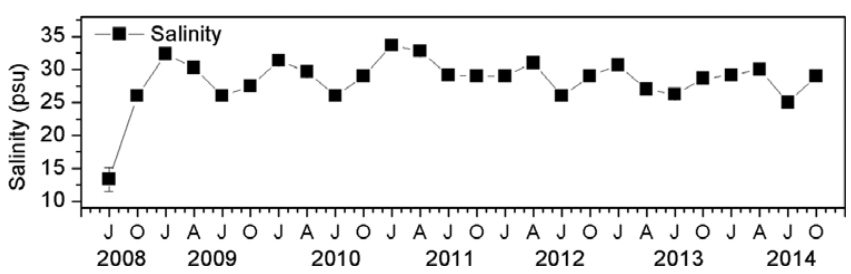

Fig. 4. Temporal variation in sea water salinity in the study area

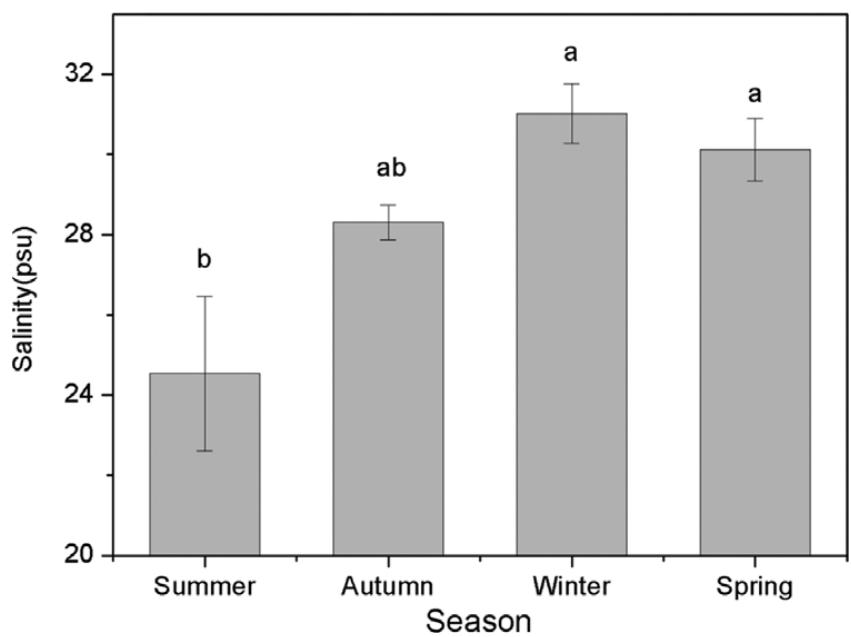

Fig. 5. Mean and SE of the salinity during the four seasons of the study period. [Different letters indicate significant differences between seasons $(p<0.05)]$

was very low because it was raining on the day on which the survey was conducted.

\section{Human disturbance}

The percent of digging for Sipunculus and clam aquaculture showed a variable trend over time (Fig. 6). No significant seasonal pattern was observed over the study period $(p>0.05)$, although temporal changes were evident. Digging covered $3.6 \%$ of the seagrass meadow. Hand collection of invertebrates, the predominant practice of aquaculture in the area, did not noticeably uproot or disturb the seagrass.

\section{Biotic parameters}

\section{Seagrass distribution and area}

At the beginning of the monitoring (July 2008) period, the area of the seagrass bed was 4.54 ha. Five years later, the area of the bed had increased to 5.26 ha (July 2013). The shape of the meadow tended to become more complicated (Fig. 1).

\section{Percent cover, shoot density, biomass and other seagrass community variables}

Most seagrass community variables showed marked inter-

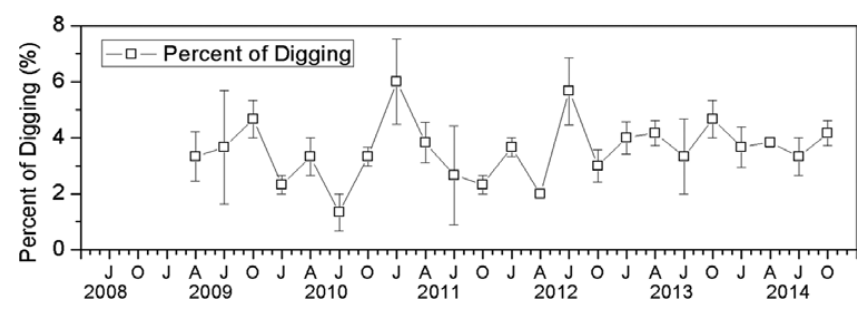

Fig. 6. Temporal variation in the percentage of the digging area (data from Apr. 2009 to Oct. 2014)

annual fluctuations and considerable seasonal variation (Fig. 7 and Table 2).

Over the $\sim 6$ years of seasonal monitoring, the mean seagrass cover of all three transects was $10.0 \pm 0.6 \%$, with a minimum of $0.1 \pm 0.2 \%$ (April 2012) and a maximum of $27.5 \pm 7.8 \%$ (July 2013) (Table 2). The seagrass cover differed significantly between spring and summer (Fig. 8A). In spring, the mean seagrass cover was $5.35 \pm 1.12 \%$. In summer, the mean $( \pm \mathrm{SE})$ seagrass cover was $13.92 \pm 1.36 \%$. In autumn, the mean seagrass cover was $10.64 \pm 1.20 \%$, and in winter, the mean cover was $8.73 \pm 0.99 \%$ (Table 2)

Leaf area index, shoot density and biomass also showed significant increases from spring to summer (Fig. 8B, C and D). Summer had the highest LAI $\left(0.28 \pm 0.04 \mathrm{~m}^{2} / \mathrm{m}^{2}\right)$, shoot density $\left(1262 \pm 119\right.$ shoots $\left./ \mathrm{m}^{2}\right)$ and biomass $(12.94 \pm 1.35 \mathrm{~g}$ $\mathrm{DW} / \mathrm{m}^{2}$ ) among the four seasons. In spring, these values were only $0.14 \pm 0.02 \mathrm{~m}^{2} / \mathrm{m}^{2}, 487 \pm 77$ shoots $/ \mathrm{m}^{2}$ and $3.84 \pm$ $1.35 \mathrm{~g} \mathrm{DW} / \mathrm{m}^{2}$, respectively (Fig. 8B, C and D).

A similar seasonal pattern was observed for above- and below-ground biomass, which also significantly increased from spring to summer (Fig. 8E). There was no significant difference in the ratio of above- to below-ground biomass among the four seasons $(\mathrm{p}>0.05)$ (Fig. 8E). Over the whole study period, the mean $\mathrm{AGB}, \mathrm{BGB}$ and $\mathrm{TB}$ values were $4.995 \pm 0.319 \mathrm{~g} \mathrm{DW} / \mathrm{m}^{2}, 3.633 \pm 0.222 \mathrm{~g} \mathrm{DW} / \mathrm{m}^{2}$, and 8.628 $\pm 0.518 \mathrm{~g} \mathrm{DW} / \mathrm{m}^{2}$, respectively (Table 2 ).

Throughout the study period, no fruit was found, and only a few flowers were found during each season (Fig. 8F). The density of flowers in spring, summer, autumn and winter was $8.66 \pm 5.38 / \mathrm{m}^{2}, 6.19 \pm 3.24 / \mathrm{m}^{2}, 3.09 \pm 1.78 / \mathrm{m}^{2}$ and 2.06 $\pm 1.46 / \mathrm{m}^{2}$, respectively (Fig. $8 \mathrm{G}$ ). There was no significant difference among the four seasons, and the mean flower density during the study period was $4.7 \pm 1.5 / \mathrm{m}^{2}$ (Table 2 ).

\section{Seagrass shoot size}

The mean canopy height and leaf width were $28.37 \pm 0.56$ $\mathrm{mm}$ and $10.01 \pm 0.20 \mathrm{~mm}$, respectively (Table 2 ; Fig. $8 \mathrm{~K}$ 


$\begin{array}{lllllll}2008 & 2009 & 2010 & 2011 & 2012 & 2013\end{array}$

Jul Oct Jan Apr Jul Oct Jan Apr Jul Oct Jan Apr Jul Oct Jan Apr Jul Oct Jan Apr Jul Oct Jan Apr Jul Oct

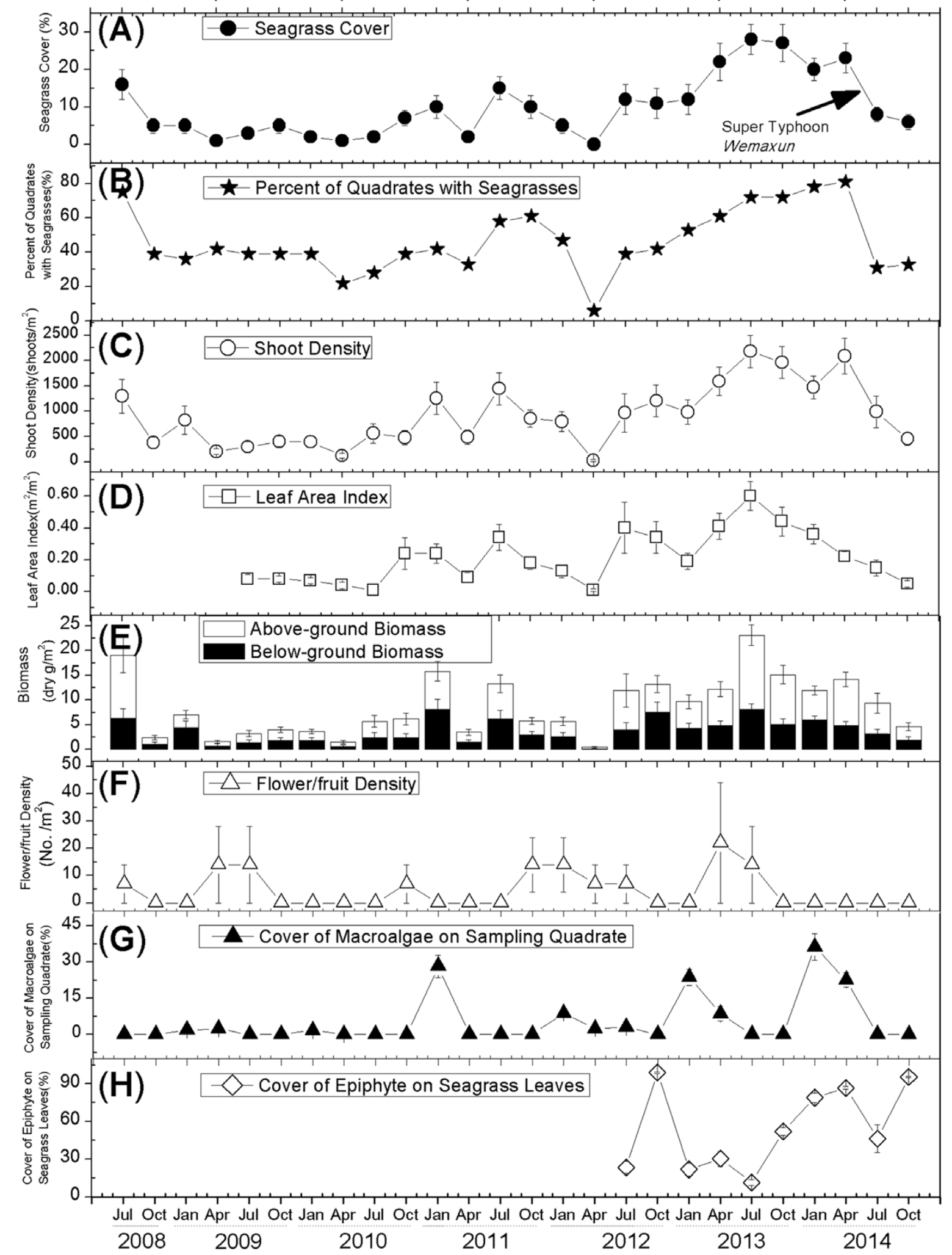

Fig. 7. Temporal variation in the attributes of the seagrass community and associated macroalgae and epiphytes (A. seagrass cover; B. percent of quadrats with seagrass; C. shoot density; D. leaf area index; E. biomass; F. flower/fruit density; G. cover of macroalgae in sampling quadrat; H. epiphyte cover on seagrass leaves) 
Table 2. Summary of yearly statistics of attributes of the seagrass meadow and associated macroalgae and epiphyte cover values

\begin{tabular}{|c|c|c|c|c|c|c|c|c|c|c|c|}
\hline \multicolumn{2}{|c|}{ Year } & $\begin{array}{l}\text { Percent } \\
\text { Cover } \\
(\%)\end{array}$ & $\begin{array}{c}\text { Shoot } \\
\text { Density } \\
\left(\text { Shoots } / \mathrm{m}^{2}\right)\end{array}$ & $\begin{array}{l}\text { Leaf Area } \\
\text { Index } \\
\left(\mathrm{m}^{2} / \mathrm{m}^{2}\right)\end{array}$ & $\begin{array}{c}\text { Above-ground } \\
\text { Biomass } \\
\left(\mathrm{DW} \mathrm{g} / \mathrm{m}^{2}\right)\end{array}$ & $\begin{array}{c}\text { Below-ground } \\
\text { Biomass } \\
\left(\mathrm{DW} \mathrm{g} / \mathrm{m}^{2}\right)\end{array}$ & $\begin{array}{c}\text { Total } \\
\text { Biomass } \\
\left(\mathrm{DW} \mathrm{g} / \mathrm{m}^{2}\right)\end{array}$ & $\begin{array}{c}\text { Above:belo } \\
\text { w Biomass } \\
\text { Ratio }\end{array}$ & $\begin{array}{l}\text { Flower/fruit } \\
\text { Density } \\
\left(\text { No. } / \mathrm{m}^{2}\right)\end{array}$ & $\begin{array}{l}\text { Macroalgae } \\
\text { Cover } \\
(\%)\end{array}$ & $\begin{array}{l}\text { Epiphyte } \\
\text { Cover (\%) }\end{array}$ \\
\hline \multirow[t]{3}{*}{$2008^{\mathrm{a}}$} & Mean & $10.3 \pm 2.3$ & $837 \pm 183$ & 1 & $7.021 \pm 1.900$ & $3.710 \pm 1.012$ & $10.732 \pm 2.803$ & $5.19 \pm 3.02$ & $3.6 \pm 3.6$ & $0.0 \pm 0.0$ & 1 \\
\hline & $\mathrm{N}$ & 72 & 72 & l & 72 & 72 & 72 & 25 & 72 & 72 & / \\
\hline & $\%$ C.V. & 188 & 185 & I & 230 & 232 & 222 & 291 & 849 & 0 & / \\
\hline \multirow[t]{3}{*}{2009} & Mean & $3.9 \pm 0.8$ & $431 \pm 80$ & $0.08 \pm 0.02$ & $1.843 \pm 0.311$ & $2.105 \pm 0.408$ & $3.947 \pm 0.687$ & $2.76 \pm 1.08$ & $7.2 \pm 5.1$ & $1.1 \pm 0.2$ & / \\
\hline & $\mathrm{N}$ & 144 & 144 & 72 & 144 & 144 & 144 & 50 & 144 & 144 & / \\
\hline & $\%$ C.V. & 237 & 224 & 183 & 203 & 233 & 209 & 277 & 846 & 215 & / \\
\hline \multirow[t]{3}{*}{2010} & Mean & $3.0 \pm 0.6$ & $390 \pm 68$ & $0.09 \pm 0.03$ & $2.430 \pm 0.461$ & $1.825 \pm 0.333$ & $4.254 \pm 0.756$ & $3.49 \pm 2.09$ & $1.8 \pm 1.8$ & $0.4 \pm 0.1$ & / \\
\hline & $\mathrm{N}$ & 144 & 144 & 144 & 144 & 144 & 144 & 43 & 144 & 144 & l \\
\hline & $\%$ C.V. & 225 & 210 & 355 & 228 & 219 & 213 & 397 & 1200 & 365 & / \\
\hline \multirow[t]{3}{*}{2011} & Mean & $9.30 \pm 1.3$ & $1011 \pm 128$ & $0.21 \pm 0.03$ & $4.931 \pm 0.723$ & $4.686 \pm 0.729$ & $9.617 \pm 1.429$ & $2.64 \pm 0.98$ & $3.6 \pm 2.5$ & $7.1 \pm 1.5$ & / \\
\hline & $\mathrm{N}$ & 144 & 144 & 144 & 144 & 144 & 144 & 69 & 144 & 144 & / \\
\hline & $\%$ C.V. & 169 & 152 & 158 & 176 & 187 & 178 & 309 & 846 & 260 & / \\
\hline \multirow[t]{3}{*}{2012} & Mean & $7.2 \pm 1.5$ & $749 \pm 136$ & $0.22 \pm 0.05$ & $4.251 \pm 0.991$ & $3.581 \pm 0.687$ & $7.832 \pm 1.596$ & $5.05 \pm 2.48$ & $7.2 \pm 3.6$ & $3.6 \pm 0.7$ & $65.6 \pm 6.8$ \\
\hline & $\mathrm{N}$ & 144 & 144 & 144 & 144 & 144 & 144 & 48 & 144 & 144 & 34 \\
\hline & $\%$ C.V. & 247 & 217 & 265 & 280 & 230 & 245 & 340 & 594 & 232 & 60 \\
\hline \multirow[t]{3}{*}{2013} & Mean & $22.4 \pm 2.3$ & $1678 \pm 148$ & $0.41 \pm 0.04$ & $9.461 \pm 0.907$ & $5.576 \pm 0.548$ & $15.036 \pm 1.410$ & $1.84 \pm 0.10$ & $9.0 \pm 6.5$ & $7.9 \pm 1.3$ & $29.2 \pm 2.6$ \\
\hline & $\mathrm{N}$ & 144 & 144 & 144 & 144 & 144 & 144 & 89 & 144 & 144 & 97 \\
\hline & $\%$ C.V. & 122 & 106 & 118 & 115 & 118 & 113 & 51 & 863 & 202 & 87 \\
\hline \multirow[t]{3}{*}{2014} & Mean & $14.1 \pm 1.6$ & $1251 \pm 142$ & $0.20 \pm 0.02$ & $6.039 \pm 0.709$ & $3.989 \pm 0.430$ & $10.027 \pm 1.104$ & $1.87 \pm 0.19$ & $0.0 \pm 0.0$ & $14.7 \pm 2.0$ & $79.8 \pm 2.6$ \\
\hline & $\mathrm{N}$ & 144 & 144 & 144 & 144 & 144 & 144 & 80 & 144 & 144 & 80 \\
\hline & $\%$ C.V. & 132 & 136 & 138 & 141 & 129 & 132 & 92 & 0 & 166 & 29 \\
\hline \multirow[t]{3}{*}{ Total } & Mean & $10.0 \pm 0.6^{* *}$ & $912 \pm 50^{* *}$ & $0.21 \pm 0.01$ & $4.995 \pm 0.319^{*}$ & $3.633 \pm 0.222$ & $8.628 \pm 0.518^{*}$ & $2.86 \pm 0.47$ & $4.7 \pm 1.5$ & $5.4 \pm 0.5$ & $54.2 \pm 2.5$ \\
\hline & $\mathrm{N}$ & 936 & 936 & 792 & 936 & 936 & 936 & 404 & 936 & 936 & 211 \\
\hline & $\%$ C.V. & 185 & 167 & 194 & 195 & 187 & 184 & 328 & 964 & 276 & 67 \\
\hline
\end{tabular}

${ }^{\mathrm{a}}$ There were no data for spring (April) and winter (January) in 2008 because monitoring began in July 2008

*Indicates the value differed significantly between years $(\mathrm{p}<0.05)$. We did not include the 2008 data in the ANOVA between years because there were no data from spring and winter in 2008

*** Indicates the value differed highly significantly between years $(\mathrm{p}<0.01)$

and L). No significant seasonal differences were observed.

\section{Chlorophyll fluorescence characteristics of leaves (Fv:Fm)}

Unlike the seasonal pattern of the basic community characteristics (e.g., cover, shoot density and biomass), the $F v: F m$ ratio was the highest $(0.730 \pm 0.007)$ and most stable (C.V. $=4.0 \%)$ in spring, followed by summer $(0.714 \pm 0.012$, C.V. $=6.9 \%)$ and autumn $(0.661 \pm 0.013$, C.V. $=7.7 \%)$ (Fig. $8 \mathrm{~J})$. The Fv:Fm ratio in winter was the lowest among the 4 seasons and was less stable $(0.648 \pm 0.035, \mathrm{C} . \mathrm{V} .=20.1 \%)$.

\section{Macroalgae and epiphytes}

The temporal variability of the macroalgae and epiphyte coverage was considerable (Fig. 8H and I). The macroalgae, dominated by Ulva spp., usually flourished in winter with a cover of $14.3 \pm 1.4 \%$. Macroalgae cover in summer and spring was low, i.e., $3.7 \pm 0.7 \%$ and $2.7 \pm 0.7 \%$, respectively. No macroalgae were observed during autumn monitoring. The average cover of macroalgae over the study period was $5.4 \pm$ $0.48 \%$ (Table 2).

Epiphyte cover on seagrass leaves was highest in autumn and winter (Fig. 8I). The lowest epiphyte cover was recorded in spring. The mean cover of epiphytes on seagrass leaves during the study period was $54.2 \pm 2.5 \%$ (Fig. 8I). Epiphyte cover was only measured from 2012 to 2014 .

\section{Correlations between seagrass dynamics and environmental factors}

Based on the correlation analysis results (Table 3), there was no significant correlation between any of the environmental attributes of the seagrass community and the variables PQS, PC, SD, BGB, TB, LAI, FD, and PD.

However, above-ground biomass (AGB) was positively affected by precipitation and visibility and negatively impacted by salinity. The above:below-ground biomass ratio (AGB:BGB ratio) was the most responsive to environmental variables, 

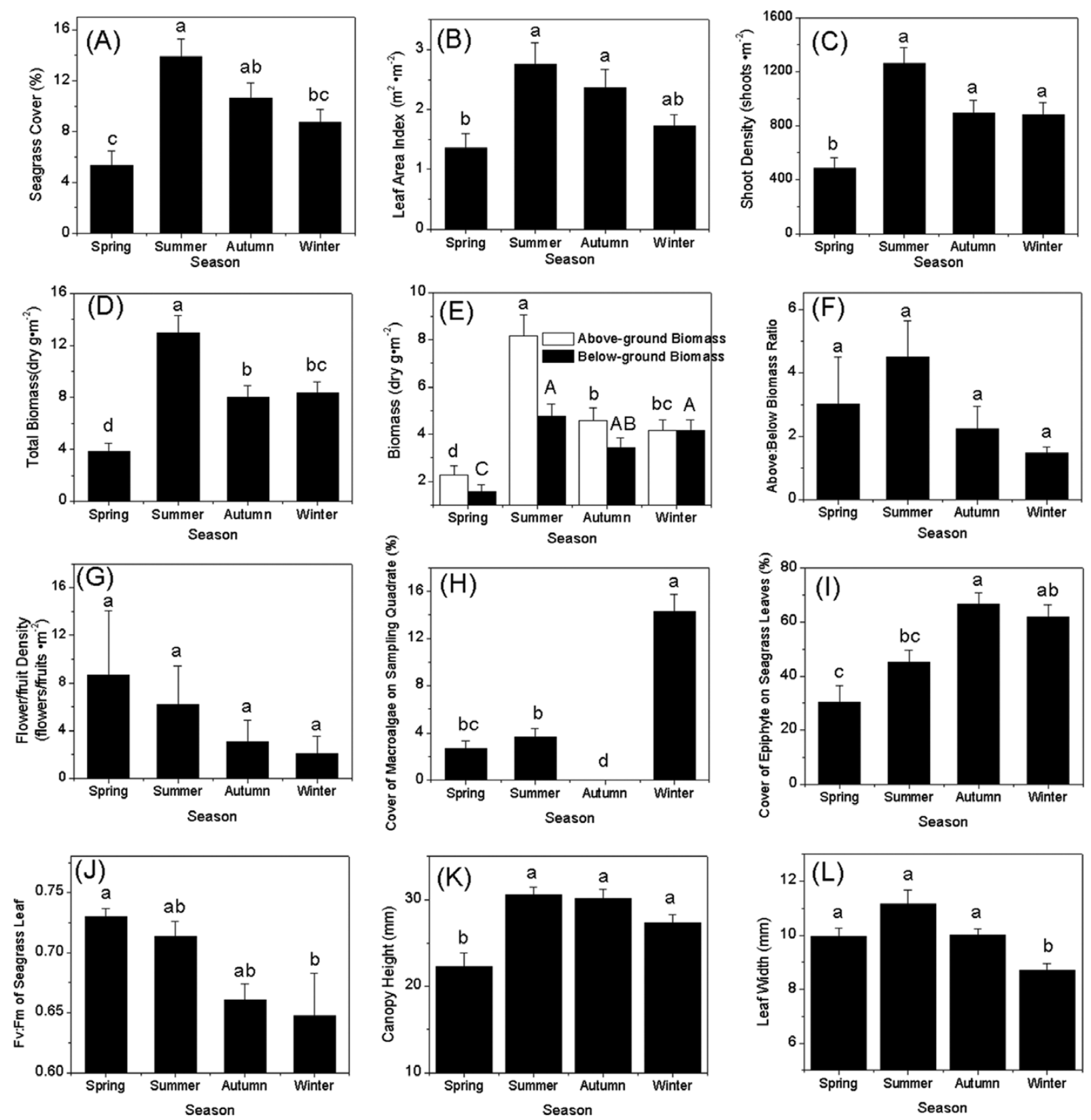

Fig. 8. Comparisons among the 4 seasons with respect to the attributes of the seagrass community, associated macroalgae, epiphyte and leaf morphology. A. seagrass cover; B. leaf area index; C. shoot density; D. total biomass; E. above- and below-ground biomass; F. above:below ground biomass ratio; G. flower/fruit density; H. cover of macroalgae in sampling quadrat; I. epiphyte cover on seagrass leaves; J. Fv:Fm of seagrass leaves; K. canopy height; L. leaf width. Different letters indicate significant differences between seasons $(\mathrm{p}<0.05)$

and positively correlated with precipitation, visibility and air temperature and negatively correlated with the 60-day wind speed and salinity. Canopy height $(\mathrm{CH})$ was only affected by visibility. Leaf width (LW) positively correlated with visibility and air temperature and negatively correlated with salinity. Macroalgae cover (MAPC) was negatively correlated with air temperature (Table 3 ).

\section{Discussion}

\section{Halophila ovalis inter-annual and seasonal variations}

Our study demonstrated strong inter-annual and seasonal dynamics of an intertidal seagrass community in the southern subtropical region of China. The seasonal average seagrass cover, above-ground biomass, below-ground biomass, total 
Table 3. Correlation analysis between seagrass dynamics and environmental factors and human-induced physical disturbances ${ }^{\#}$

\begin{tabular}{|c|c|c|c|c|c|c|c|c|c|c|c|c|c|c|}
\hline & & PQS & $\mathrm{PC}$ & SD & AGB & BGB & AGB:BGB ratio & TB & LAI & $\mathrm{CH}$ & LW & FD & MAPC & EPC \\
\hline \multirow[t]{4}{*}{ Precipitation } & $P \_b 7$ & 0.322 & 0.162 & 0.209 & 0.388 & 0.149 & $0.401^{*}$ & 0.309 & -0.070 & 0.032 & 0.292 & 0.016 & -0.152 & -0.007 \\
\hline & $P \_b 15$ & 0.285 & 0.152 & 0.165 & $0.425^{*}$ & 0.166 & $0.474^{*}$ & 0.340 & 0.001 & 0.083 & 0.425 & 0.156 & -0.227 & -0.299 \\
\hline & $P_{-} b 30$ & 0.271 & 0.152 & 0.148 & 0.373 & 0.165 & 0.387 & 0.306 & 0.145 & 0.031 & 0.338 & 0.136 & -0.329 & -0.371 \\
\hline & $P \_b 60$ & 0.235 & 0.230 & 0.175 & $0.435^{*}$ & 0.206 & $0.508^{* *}$ & 0.362 & 0.230 & 0.307 & 0.360 & -0.029 & $-0.393^{*}$ & 0.005 \\
\hline \multirow[t]{4}{*}{ Wind speed } & WS_b7 & 0.111 & 0.023 & 0.079 & 0.050 & 0.108 & -0.092 & 0.075 & -0.030 & -0.072 & -0.104 & -0.175 & $0.479^{*}$ & -0.468 \\
\hline & $W S \_b 15$ & 0.023 & -0.120 & -0.025 & -0.087 & 0.042 & -0.265 & -0.039 & -0.08 & -0.225 & -0.226 & -0.029 & $0.484^{*}$ & -0.521 \\
\hline & WS_b30 & 0.036 & -0.084 & -0.030 & -0.080 & 0.032 & -0.273 & -0.038 & -0.003 & -0.281 & -0.103 & 0.147 & 0.337 & $-0.742^{*}$ \\
\hline & WS_b60 & -0.122 & -0.276 & -0.174 & -0.253 & -0.088 & $-0.403^{*}$ & -0.198 & -0.175 & -0.387 & -0.258 & 0.131 & 0.369 & -0.537 \\
\hline \multirow[t]{4}{*}{ Visibility } & $V \_b 7$ & 0.001 & 0.123 & 0.085 & 0.315 & 0.082 & $0.494^{*}$ & 0.235 & 0.101 & 0.376 & 0.423 & 0.071 & -0.186 & -0.127 \\
\hline & $V \_b 15$ & 0.001 & 0.164 & 0.132 & 0.375 & 0.113 & $0.548^{* *}$ & 0.286 & 0.136 & $0.394^{*}$ & $0.489^{*}$ & 0.067 & -0.303 & -0.189 \\
\hline & $V \_b 30$ & 0.042 & 0.215 & 0.178 & $0.416^{*}$ & 0.159 & $0.551^{* *}$ & 0.331 & 0.167 & $0.412^{*}$ & $0.530^{*}$ & 0.042 & -0.322 & -0.192 \\
\hline & $V \_b 60$ & 0.075 & 0.228 & 0.190 & 0.384 & 0.190 & $0.418^{*}$ & 0.323 & 0.237 & 0.365 & $0.496^{*}$ & 0.007 & -0.383 & -0.125 \\
\hline \multirow[t]{4}{*}{ Air Temperature } & Tm_b7 & -0.154 & -0.026 & -0.084 & 0.094 & -0.191 & $0.493^{*}$ & -0.016 & 0.020 & 0.150 & $0.611^{* * *}$ & 0.108 & $-0.700^{* * *}$ & 0.041 \\
\hline & Tm_b15 & -0.062 & 0.082 & 0.007 & 0.168 & -0.116 & $0.518^{* *}$ & 0.062 & 0.105 & 0.206 & $0.657^{* *}$ & 0.082 & $-0.663^{* *}$ & 0.046 \\
\hline & Tm_b30 & -0.051 & 0.102 & 0.019 & 0.197 & -0.073 & $0.498^{* *}$ & 0.098 & 0.136 & 0.241 & $0.700^{* *}$ & 0.120 & $-0.679^{* *}$ & -0.068 \\
\hline & Tm_b60 & -0.006 & 0.122 & 0.047 & 0.224 & 0.026 & $0.392^{*}$ & 0.155 & 0.189 & 0.251 & $0.622^{* *}$ & 0.077 & $-0.642^{* *}$ & -0.087 \\
\hline Salinity & & -0.304 & -0.240 & -0.167 & $-0.454^{*}$ & -0.153 & $-0.544^{* *}$ & -0.353 & -0.239 & -0.262 & $-0.683^{* *}$ & -0.227 & 0.292 & 0.492 \\
\hline PD & & 0.226 & 0.312 & 0.282 & 0.355 & 0.323 & 0.214 & 0.356 & 0.346 & 0.178 & -0.114 & -0.040 & 0.364 & -0.312 \\
\hline
\end{tabular}

"PQS: percentage number of quadrats with seagrass present relative to the total quadrats; PC: seagrass percent cover; SD: shoot density; AGB: aboveground biomass; BGB: below-ground biomass; TB: total biomass; LAI: leaf area index; CH: canopy height; LW: leaf width; FD: flower/fruit density; MAPC: percent cover of macroalgae in sampling quadrat; EPC: percent epiphyte cover on seagrass leaves; PD: the percent area that had been dug $P \_b x$ : total precipitation over x days before the seasonal monitoring, e.g., $P \_b 10$ represents total precipitation over the 10 days before the seasonal monitoring. $W S \_b \mathrm{x}$ : mean wind speed over $\mathrm{x}$ days before the seasonal monitoring. $V \_b \mathrm{x}$ : mean visibility over $\mathrm{x}$ days before the seasonal monitoring. $T m_{-} b \mathrm{x}$ : mean temperature over $\mathrm{x}$ days before the seasonal monitoring

"Means the correlation is significant $(\mathrm{p}<0.05)$

${ }^{* *}$ Means the correlation is highly significant $(\mathrm{p}<0.01)$

biomass and shoot density ranged widely within two orders of magnitude (e.g., shoot density and percent cover: 29 shoots $/ \mathrm{m}^{2}$ in April 2012 vs. 2180 shoots $/ \mathrm{m}^{2}$ in July 2013, and $0.1 \%$ in April 2012 vs. $27.5 \%$ in July 2013, respectively). The seagrass meadow almost disappeared in April 2012, but it subsequently regrew. Based on these results, we show that long-term regular monitoring is significant in identifying changes in coastal wetland resources (Short et al. 2014). In this case, if the monitoring stopped in April 2012, a wrong conclusion may have been drawn, and the meadow may have been considered as seriously degraded. Substantial temporal fluctuations in intertidal seagrass parameters were also found for another Halophila species, i.e., Halophila beccarii in this region (southern China) (Qiu et al. 2013), some other small intertidal seagrass species, such as $Z$. japonica along the south coast of Korea (Kim et al. 2016) and Zostera noltii in SW Netherlands (Vermaat and Verhagen 1996). It seems that some environmental factors such as low water temperature, longer exposure time in winter, extreme high water temperature in summer and poor atmospheric visibility from January to
March may explain the sharp decrease of seagrass growth from July 2011 to April 2012 in the Guangxi meadow. The causes of the dramatic increase of seagrass cover and shoot density from April 2012 to April 2014 needs further research and analysis.

Some of the seagrass community parameters differed significantly among seasons, especially between spring and summer. The highest percent cover, leaf area index, shoot density, above-ground biomass, below-ground biomass, total biomass, canopy height and leaf width values were measured in summer, while the lowest values for these parameters were observed in winter or spring. Our present results coincide with the work conducted by Jankowska et al. (2014), who monitored Zostera marina vegetation in the southern Baltic Sea and found the highest values of shoot density, leaf length, and biomass in July, with the lowest values in March. Furthermore, the greatest shoot size and highest biomass were measured in summer, and their smallestllowest counterparts were measured in winter and early spring by Zhang et al. (2014), who conducted Z. marina monitoring in North China. However, 
Huong et al. (2003) observed that H. ovalis in Ha Long Bay (northern Vietnam) reached maximum shoot densities in September-October. These authors ascribed the pattern to the rainy season, which brings turbid water during May-August, possibly limiting light availability and therefore seagrass growth. At the study site in the present work, located in an open coastal area and free of the impacts of estuarine-sourced turbid water during the rainy season, maximum values of many of the seagrass community parameters were measured in summer due to fewer effects from turbidity.

\section{Factors affecting $\boldsymbol{H}$. ovalis growth and leaf morphology}

In previous studies, the temporal dynamics of a seagrass community have been attributed to changes in various factors, such as temperature and irradiance (Lee et al. 2007), rainfall (Lin and Shao 1998), water-column nutrient concentration (nutrient load) and sedimentation (Short et al. 2014). Tidal exposure (Erftemeijer and Herman 1994; Park et al. 2016), hydrodynamism (Robbins and Bell 2000), wind speed (Lin and Shao 1998), salinity, UV-B radiation, and sediment depth (Kuo and Lin 2010) have also been shown to influence seagrass temporal dynamics. Additionally, human-induced disturbances (Short et al. 2014), herbivory (Vermaat and Verhagen 1996), and even sunspots (Marques et al. 2014) have been implicated. However, the effects of environmental variables and humaninduced disturbances on seagrass temporal dynamics are species-specific, and the environmental variables may interact.

Above-ground biomass and the AGB:BGB of $H$. ovalis were both significantly correlated with precipitation in our study, and the highest correlation was observed with precipitation in the previous 60 days (Table 3). Above-ground biomass, AGB:BGB and leaf width were positively correlated with both atmospheric visibility and temperature, with the highest correlation occurring with temperature. Visibility (light) and temperature are related because in shallow water, much of the temperature effect is a result of sunny conditions and solar warming. The below-ground biomass of $H$. ovalis was not significantly correlated with environmental parameters. The analysis shows that the above-ground parts of $H$. ovalis were much more sensitive to external environmental conditions than the below-ground parts.

The irradiance measured by the weather station does not represent the irradiance reaching the seagrass leaves on the sea bottom because the irradiance needs to pass through the water layer, and the visibility of the water column and the duration of tidal exposure finally determine how much irradiance reaches the seagrasses. At the study site, the duration of exposure during the day time from August to October (daily average exposure time ranged between 4.6 5.9 hours) was low compared with the other months (e.g., 9.4 hours of daily average exposure time in March). Furthermore, the highest epiphyte cover among the four seasons was measured in autumn (October). The combination of the tidal submergence and epiphytic cover in October may have resulted in relatively weak irradiance reaching the seagrass plants. The macroalgal (pleustophytic or epiphytic forms) and microalgal blooms and suspended matter may also partly decrease the irradiance reaching the seagrass plants on the seabed (Brun et al. 2003; Kim et al. 2015; Onuf 1996). Unlike the growth pattern of other macroalgae in Northern China (Liu et al. 2009) and the seagrasses in the present study area, which both usually peak in summer, the Ulva spp. found in our study tended to flourish in winter. The cover of pleustophytic macroalgae in winter in the study area was significantly higher than in any other seasons. This might decrease the irradiance reaching the seagrasses at the bottom. All of these factors might explain the complicated interaction of irradiance (light) and seagrass growth.

Our data also suggest that salinity may be another important factor influencing $H$. ovalis community dynamics. Inappropriate salinity can reduce the growth rate of seagrasses and even cause eco-physiological injuries (Collier et al. 2014; Sidik et al. 2010). Significantly negative correlations within a salinity range of ca. 25 31 psu were observed between seawater salinity and above-ground biomass $(r=-0.454, \mathrm{p}<0.05)$ and leaf width $(\mathrm{r}=-0.683, \mathrm{p}<0.01)$. Usually, the salinity in the study area was higher than 28 psu except in summer, when the average salinity was approximately $25 \mathrm{psu}$. H. ovalis, although regarded as a euryhaline seagrass species, has better growth performance in salinity of approximately 25 psu compared with 29 psu under laboratory conditions (Sidik et al. 2010). In a controlled experiment of $H$. ovalis subjected to salinity ranging from 3 to 36 psu for 10 weeks, Collier et al. (2014) found higher shoot density and leaf area under a salinity of 12 21 psu compared with the other treatments. This suggests that H. ovalis in our study area might generally grow under salinities that are higher than the optimal state.

Maximal electron quantum yield $(F v: F m)$ is a commonly accepted rapid and non-destructive indicator of plant stress that affects photosystem II (Beer et al. 2006; Ralph and Burchett 1995). In the current study, the $F v: F m$ ratio of the leaves was generally low, with the highest value of $0.730 \pm$ 
0.007 in spring, followed by $0.714 \pm 0.012$ in summer, 0.661 \pm 0.013 in autumn and $0.648 \pm 0.035$ in winter. These values are equal to or lower than those observed for $H$. ovalis in Taylor's Bay, Sydney, N.S.W., Australia, where the Fv:Fm value was consistently reported as approximately 0.73 (Ralph and Burchett 1995). This result suggests that the ecological growth conditions of $H$. ovalis in our study site could be physiologically sub-optimal, especially in winter and autumn, a speculation possibly strengthened by a comparison of biomass from our study with other sites. The biomass of $H$. ovalis in our study $\left(21^{\circ} \mathrm{N}\right)$, which ranged from 0.4 to $23 \mathrm{~g} \mathrm{DW} / \mathrm{m}^{2}$, is much lower than that measured in Canning Estuary, Western Australia $\left(31 \sim 32^{\circ} \mathrm{S}\right)$, where $H$. ovalis biomass can reach a maximum value of over $120 \mathrm{~g} \mathrm{DW} / \mathrm{m}^{2}$ (Hillman et al. 1995), and in northern Vietnam $\left(20^{\circ} \mathrm{N}\right)$, where the highest biomass of $70 \mathrm{~g} \mathrm{DW} / \mathrm{m}^{2}$ within a year was measured during SeptemberOctober (Huong et al. 2003).

Globally, eutrophication is one of the primary causes of seagrass decline (Cardoso et al. 2004; Duarte 2002; Short et al. 2006a). Based on the preliminary chemical analysis of the sea water in the study site (Table 1), no nutrient loading was observed. In addition, no obvious seagrass decline was detected during our 6-year monitoring. Nevertheless, it is difficult to link seagrass dynamics with sea water nutrient loading because long-term time-series monitoring of sea water is lacking and algae quickly take up nutrients from sea water.

\section{Human disturbance of seagrasses}

Clam/sandworm harvesting is common in southern China's intertidal seagrass beds. The harvesting activities usually encompass digging and tilling the sediment, which may damage the photosynthetic tissues of the seagrass or cause plant burial, resulting in reduced seagrass cover (Park et al. 2011). Previous studies showed that these activities (especially using mechanical methods) have negative effects on seagrass growth (Cabaço et al. 2005; Neckles et al. 2005); however, there are some other reports indicating that clam raking or digging did not appreciably impact the seagrass (Boese 2002; Park et al. 2011). In our study, there was no significant correlation between the degree of digging in the seagrass meadow and the seagrass meadow parameters. The possible reasons may be the combination of: 1) the disturbance degree caused by harvesting activities was relatively small, as the above results showed that generally less than $5 \%$ of the area was dug or buried by the sediment. 2) The strong resilience of $\mathrm{H}$. ovalis. The recovery times after human disturbances are largely dependent on the growth characteristics of the seagrass species impacted (Neckles et al. 2005), and whether the seagrass population declines are related to the tradeoff between shoot recruitment and mortality rate (Marbà et al. 1996b). Only five months after disturbance, the shoot density and biomass of a colonizing seagrass species, $Z$. japonica, almost recovered to the levels reported before the clamming activity (Park et al. 2011). H. ovalis, usually regarded as a small colonizing species or an opportunistic species (Duarte 1991), among the fastest growing seagrass species (Marbà and Duarte 1998), with a horizontal rhizome elongation rate ca. 177 times faster than Posidonia oceanica, should have very strong resilience in response to disturbances.

\section{Conclusions}

In summary, we have demonstrated that the long-term monitoring of an intertidal $H$. ovalis community in southern China showed strong inter-annual and seasonal variations. Generally, the community exhibited the best performance (highest seagrass cover, leaf area, shoot density and total biomass) in summer and the worst in spring. The temporal variations in some seagrass community attributes (e.g., aboveground biomass) were significantly affected by precipitation, visibility, and salinity (negative effect), while leaf width was significantly correlated with temperature, visibility and salinity (negative effect). The above:below-ground biomass ratio and leaf width of $H$. ovalis were shown to be the most sensitive plant parameters in assessing environmental interactions. Precipitation had a positive effect on above- and below-ground seagrass growth and a related negative effect on salinity. Temperature was a major factor influencing the seagrass community (both macroalgae and seagrass), with the temperature data showing an inverse relationship between seagrass and macroalgae. However, further studies are needed in order to determine the interaction effects of these driving forces because some driving forces may be interactive and self-correlated.

Our research findings also show that long-term regular monitoring (using SeagrassNet, for example) is valuable in understanding the relationships between environmental variables and seagrass and can be used to demonstrate human impacts (or a lack of human impacts).

\section{Acknowledgments}

We thank Sen Li, Cong Zeng, Liangdong Huang, Leixian 
Li, Xianjin He, Zhinan Su, Meiqiu Wei, Siyong Tan, Meng Li, Lianghao Pan, Xiaofang Shi, Wenai Liu, Jiangling Wei, Ruqiong Zhou, Mingliu Yang, Yongze Xing, Yuansong Chen, Xingwen Zheng, Sheng Peng, Yajun Shi, Xin Wang, Xiang Ni, Jun Jiang, Heng Jiang, Wenli Wu, Lingyu Huang, Xueqin Gao, Lili Wu, Zhi Li, Liang Liao, Yan Yang, Yanhua Yang, Wen Yang, etc., for their field and laboratory assistance in the past 6 years. This research was supported by the Global Seagrass Monitoring Networking (SeagrassNet), the Guangxi Science Foundation (2012GXNSFBA053141, 2010GXNSFE013002), the Guangxi Distinguished Experts Post "Mangrove and Seagrass Ecosystem Conservation \& Ecological Monitoring”, Jackson Estuarine Laboratory (contribution number 559), University of New Hampshire and the National Science \& Technology Basic Work Program (2015FY110600).

\section{References}

Alcoverro T, Duarte CM, Romero J (1995) Annual growth dynamics of Posidonia oceanica - contribution of large-scale versus local factors to seasonality. Mar Ecol-Prog Ser 120:203-210

Alexandre A, Santos R, Serrao E (2005) Effects of clam harvesting on sexual reproduction of the seagrass Zostera noltii. Mar Ecol-Prog Ser 298:115-122

Beer S, Mtolera M, Lyimo T, Björk M (2006) The photosynthetic performance of the tropical seagrass Halophila ovalis in the upper intertidal. Aquat Bot 84:367-371

Boese BL (2002) Effects of recreational clam harvesting on eelgrass (Zostera marina) and associated infaunal invertebrates: in situ manipulative experiments. Aquat Bot 73:63-74

Brun FG, Hernandez I, Vergara JJ, Perez-Llorens JL (2003) Growth, carbon allocation and proteolytic activity in the seagrass Zostera noltii shaded by Ulva canopies. Funct Plant Biol 30:551-560

Cabaço S, Alexandre A, Santos R (2005) Population-level effects of clam harvesting on the seagrass Zostera noltii. Mar EcolProg Ser 298:123-129

Cardoso PG, Pardal MA, Lilleb AI, Ferreira SM, Raffaelli D, Marques JC (2004) Dynamic changes in seagrass assemblages under eutrophication and implications for recovery. J Exp Mar Biol Ecol 302:233-248

Collier CJ, Villacorta-Rath C, van Dijk KJ, Takahashi M, Waycott M (2014) Seagrass proliferation precedes mortality during hypo-salinity events: a stress-induced morphometric response. PLoS One 9:e94014

den Hartog C, Yang Z (1990) A catalogue of the seagrasses of China. Chin J Oceanol Limn 8:74-91

Duarte CM (1991) Allometric scaling of seagrass form and productivity. Mar Ecol-Prog Ser 77:289-300
Duarte CM (2002) The future of seagrass meadows. Environ Conserv 29:192-206

Duarte CM, Fourqurean JW, Krause-Jensen D, Olesen B (2006) Dynamics of seagrass stability and change. In: Larkum AWD, Orth RJ, Duarte CM (eds) Seagrasses: biology, ecology and conservation. Springer, Dordrecht, pp 271-294

Erftemeijer PLA, Herman PMJ (1994) Seasonal changes in environmental variables, biomass, production and nutrient contents in two contrasting tropical intertidal seagrass beds in South Sulawesi, Indonesia. Oecologia 99:45-59

Fonseca MS, Kenworthy WJ, Thayer GW (1998) Guidelines for the conservation and restoration of seagrasses in the United States and adjacent waters. NOAA Coastal Ocean Office, Maryland, NOAA Coastal Ocean Program Decision Analysis Series No. 12, $222 \mathrm{p}$

Hillman K, McComb AJ, Walker DI (1995) The distribution, biomass and primary production of the seagrass Halophila ovalis in the Swan/Canning Estuary, Western Australia. Aquat Bot 51:1-54

Huong TTL, Vermaat JE, Terrados J, Van Tien N, Duarte CM, Borum J, Tri NH (2003) Seasonality and depth zonation of intertidal Halophila ovalis and Zostera japonica in Ha Long Bay (northern Vietnam). Aquat Bot 75:147-157

Jankowska E, Włodarska-Kowalczuk M, Kotwicki L, Balazy P, Kuliński K (2014) Seasonality in vegetation biometrics and its effects on sediment characteristics and meiofauna in Baltic seagrass meadows. Estuar Coast Shelf S 139:159-170

Kim J-H, Kim SH, Kim YK, Park J-I, Lee K-S (2016) Growth dynamics of the seagrass Zostera japonica at its upper and lower distributional limits in the intertidal zone. Estuar Coast Shelf S 175:1-9

Kim J-H, Park SH, Kim YK, Kim SH, Park J-I, Lee K-S (2014) Seasonal growth dynamics of the seagrass Zostera caulescens on the eastern coast of Korea. Ocean Sci J 49:391-402

Kim YK, Kim SH, Lee K-S (2015) Seasonal growth responses of the seagrass Zostera marina under severely diminished light conditions. Estuar Coast 38:558-568

Kuo Y-M, Lin H-J (2010) Dynamic factor analysis of long-term growth trends of the intertidal seagrass Thalassia hemprichii in southern Taiwan. Estuar Coast Shelf S 86:225-236

Lee K-S, Park SR, Kim YK (2007) Effects of irradiance, temperature, and nutrients on growth dynamics of seagrasses: a review. $\mathrm{J}$ Exp Mar Biol Ecol 350:144-175

Lee SY, Kim JB, Lee SM (2006) Temporal dynamics of subtidal Zostera marina and intertidal Zostera japonica on the southern coast of Korea. Mar Ecol 27:133-144

Lin HJ, Shao KT (1998) Temporal changes in the abundance and growth of intertidal Thalassia hemprichii seagrass beds in southern Taiwan. Bot Bull Acad Sin 39:191-198

Liu F, Pang SJ, Chopin T, Xu N, Shan TF, Gao SQ, Sun S (2009) The dominant Ulva strain of the 2008 green algal bloom in the Yellow Sea was not detected in the coastal waters of Qingdao 
in the following winter. J Appl Phycol 22:531-540

Marbà N, Cebrian J, Enriquez S, Duarte CM (1996a) Growth patterns of western Mediterranean seagrasses: species-specific responses to seasonal forcing. Mar Ecol-Prog Ser 133:203-215

Marbà N, Duarte CM (1998) Rhizome elongation and seagrass clonal growth. Mar Ecol-Prog Ser 174:269-280

Marbà N, Duarte CM, Cebrian J, Gallegos ME, Olesen B, SandJensen K (1996b) Growth and population dynamics of Posidonia oceanica on the Spanish Mediterranean coast: elucidating seagrass decline. Mar Ecol-Prog Ser 137:203-213

Marques LV, Short FT, Creed JC (2014) Sunspots drive seagrasses. Biol Rhythm Res 46:63-68

Meling-Lopez AE, Ibarra-Obando SE (1999) Annual life cycles of two Zostera marina L. populations in the Gulf of California: contrasts in seasonality and reproductive effort. Aquat Bot 65:59-69

NMDIS (2012) Tide table 2013 (vol. 3) from the Taiwan straits to the Beibu gulf. National Marine Data and Information Service (NMDIS), Ocean Press, Beijing, 587 p

Neckles HA, Short FT, Barker S, Kopp BS (2005) Disturbance of eelgrass Zostera marina by commercial mussel Mytilus edulis harvesting in Maine: dragging impacts and habitat recovery. Mar Ecol-Prog Ser 285:57-73

Nguyen VX, Detcharoen M, Tuntiprapas P, Soe-Htun U, Sidik JB, Harah MZ, Prathep A, Papenbrock J (2014) Genetic species identification and population structure of Halophila (Hydrocharitaceae) from the Western Pacific to the Eastern Indian Ocean. BMC Evol Biol 14:92. doi: 10.1186/1471-2148-14-9292

Onuf CP (1996) Sea grass response to long-term light reduction by brown tide in upper Laguna Madre, Texas: distribution and biomass patterns. Mar Ecol-Prog Ser 138:219-231

Park SR, Kim S, Kim YK, Kang CK, Lee KS (2016) Photoacclimatory responses of Zostera marina in the intertidal and subtidal zones. PLoS One 11:e0156214. doi:10.1371/journal.pone.0156214

Park SR, Kim YK, Kim J-H, Kang C-K, Lee K-S (2011) Rapid recovery of the intertidal seagrass Zostera japonica following intense Manila clam (Ruditapes philippinarum) harvesting activity in Korea. J Exp Mar Biol Ecol 407:275-283

Qiu G, Fan H, Li Z, Liu G, Shi Y, Li S (2013) Population dynamics and seed banks of the threatened seagrass Halophila beccarii in Pearl Bay, Guangxi. Acta Ecol Sin 33:6163-6172

Ralph PJ, Burchett MD (1995) Photosynthetic responses of the seagrass Halophila ovalis (R. Br.) Hook. f. to high irradiance stress, using chlorophyll a fluorescence. Aquat Bot 51:55-66

Ralph PJ, Gademann R, Dennison WC (1998) In situ seagrass photosynthesis measured using a submersible, pulse-amplitude modulated fluorometer. Mar Biol 132:367-373
Robbins BD, Bell SS (2000) Dynamics of a subtidal seagrass landscape: seasonal and annual change in relation to water depth. Ecology 81:1193-1205

Short FT, Coles R, Fortes MD, Victor S, Salik M, Isnain I, Andrew J, Seno A (2014) Monitoring in the Western Pacific region shows evidence of seagrass decline in line with global trends. Mar Pollut Bull 83:408-416

Short FT, Koch EW, Creed JC, Magalhaes KM, Fernandez E, Gaeckle JL (2006a) SeagrassNet monitoring across the Americas: case studies of seagrass decline. Mar Ecol 27:277-289

Short FT, Mckenzie LJ, Coles RG, Vidler KP, Gaeckle JL (2006b) SeagrassNet manual for scientific monitoring of seagrass habitat (Worldwide edition). University of New Hampshire Publication, Durham, $75 \mathrm{p}$

Sidik BJ, Harah ZM, Fakhrulddin IM, Anuar MSK, Arshad A (2010) Growth performance of Malaysian's spoongrass, Halophila ovalis (R.Br.) Hooker f. under different substrate, salinity and light regime. Coast Mar Sci 34:103-107

SAQSIQ (2007) The specification for marine monitoring-part 4: seawater analysis. The State Administration of Quality Supervision, Inspection and Quarantine (SAQSIQ), China Standards Press, Beijing, $162 \mathrm{p}$

UNEP (2008) National reports on seagrass in the South China Sea. UNEP/GEF/SCS Technical Publication No. 12

Vermaat JE, Verhagen FCA (1996) Seasonal variation in the intertidal seagrass Zostera noltii Hornem.: coupling demographic and physiological patterns. Aquat Bot 52:259-281

Xun Z, Ruan C, Yang Y, Fang B, Ou Y (2006) Tidal effects of groundwater levels in the coastal aquifers near Beihai, China. Environ Geol 51:517-525

Zhang PD, Liu YS, Guo D, Li WT, Zhang Q (2016) Seasonal variation in growth, morphology, and reproduction of eelgrass Zostera marina on the eastern coast of the Shandong Peninsula, China. J Coastal Res 32:315-322

Zhang X, Zhou Y, Liu P, Wang F, Liu B, Liu X, Yang H (2015) Temporal pattern in biometrics and nutrient stoichiometry of the intertidal seagrass Zostera japonica and its adaptation to air exposure in a temperate marine lagoon (China): implications for restoration and management. Mar Pollut Bull 94:103-113

Zheng F, Qiu G, Fan H, Zhang W (2013) Diversity, distribution and conservation of seagrass species in China. Biodivers Sci 21:517-526

Zhou Y, Liu X, Liu B, Liu P, Wang F, Zhang X, Yang H (2015) Unusual pattern in characteristics of the eelgrass Zostera marina L. in a shallow lagoon (Swan Lake), north China: implications on the importance of seagrass conservation. Aquat Bot 120:178184 